\title{
XIII. Analysis of a stone called the gadolinite; with an account of some of the properties of the new earth it contains
}

\section{Vauquelin}

To cite this article: C. Vauquelin (1801) XIII. Analysis of a stone called the gadolinite; with an account of some of the properties of the new earth it contains, Philosophical Magazine Series 1, 8:32, 366-375, DOI: $10.1080 / 14786440108562658$

To link to this article: http://dx.doi.org/10.1080/14786440108562658

曲 Published online: 25 Jan 2010.

Submit your article to this journal $₫$

Џll Article views: 2

Q View related articles $\sqsubset$ 
the tympanum, and communicated the impreffions immediately to the internal organ. This not happening for fome months after the membrane was deftroyed, probably arofe from the inflammation of the tympanum confining the ftapes, and rendering its vibrations imperfect.

That founds can be communicated with accuracy by the bones of the ikull to the internal organ, when received from folid or liquid fubftances, has long been well underftond.

That the membrana tympani is incapable of perfectly anfwering this purpofe, when founds are propagated through air, has been a generally received opinion; to refute which, was the object of ny former paper. That, in cafes in which the membrana tympani has been deftroyed, the air is capable of acting with fufficient force upon the ftapes to communicate vibrations to it, and to produce on the internal organ the neceffary effect for perfect hearing, is completely afcertained by Mr. Cooper's obfervations.

XIIT. Analyfss of a Stone called the Gadolinite; witb an Account of fome of the Properties of the nequ Eartb it contains. By C. Vauaublix *.

$\mathrm{T}$

HE number of fimple bodies, and particularly that of earths, has been greatly increafed within a few years paft; and if chemiftry go on fill thus advancing, it is to be apprehended that the time may arrive when the human mind will not be able to embrace all the combinations produced by the multitude of fimple bodies.

But the analogy which exilts between certain claffes of natural fubitances, gives clicmilts reafon to fufpect that they contain a common generating principle, and affords them a hope that fome fortunate chance, or an experiment made by fome man of genius, will reduce them all to one fingle kind, either by difengaging them from thofe principles which eftablifh differences between them, or by combining thefe fame elements to thofe which are fimple.

* From the Annales de Cbimie, No. 107. 
Till chemical means are brought to that degree of perfection, we muft make known thore bodies which, on account of their peculiar properties, we cannot refer to any of thofe already known, and which, till a new order be eftablithed, we are obliged to confider as new fubltances. An attentive examination of their properties is of great importance; for, even though they may be ouly modifications of bodies already known, it may happen, of which we have many inftances, that their qualities may become ufeful to the arts and to manufactures, and, in any event, it is better to err hrough excefs than deficiency.

With this view I thall here defcribe, with fome details, the properties of a new earth difcovered by $M$. Gadolin, and which has been examined by M. Ekeberg under new points of view.

I thall firt give a thort defcription of the ftone, and therr cxplain the different proceffes which I employed to analyfe it; and fhall conclude with indicating the principal properties that characterife the new earth it contains. The greater part of the obfervations I thall make on this fubject, may have been alrealy publithed by the chemilts above menmentioned; but their works being not much known, I have thought it my duty to act in this manner, that the prefent difcovery may be better propagated.

I thall, however, repeat what has been communicated to me by M. Manthey, profeflor of chemiftry at Copenhagen, to whom both Haüy and I are indebted for a large quantity of matter containing this new earth *.

In $1794, \mathrm{M}$. Gadolin difcovered this earth; and his labour on the fubject was printed in the Memoirs of the Academy of Sweden, and in Crell's Chemical Annals for the year 1796. M. Ekeberg, about two years ago, began an analyfis of the fame ftone, and confirmed the refults of M. Gadolin. To the new earth he gave the name of Itiria, from Ytterley, a place in Sweden, where it is found. A. Ahort mention of it was made alfo in the Annales de

* Trofeffor A bildgard, alfo, has had the goodnefs to fend me a pretty large quantity of this ftone, which enabled me to vary my experiments, and to difcuier the characterifing properties of the new earth it contains. 
Cbimie, No. roo. This earth, according to him, exilts in the gadolinite in the proportion of 0.47 Accompanied by filex - 0.25 Oxyd of iron - - 0.18 Alumine - $\quad-\quad 0.04$

He defcribes alfo fome of the properties poffeffed by this new earth when freed from all the bodies united to it in the ftone, and which are as follows:- "All its combinations with acids have a fweet tafte like that of the falts of lead, but a little more aftringent; with the fulphuric and acetic acids it forms cryftallifable falts which do not change in the air; with nitric acid it gives a radiating mafs, and with the muriatic acid nothing that can cryftallife.

\section{Cbaracters of tbe Stone.}

Ift, This fubftance has a black colour, and its duft is of a blackith gray.

$2 \mathrm{~d}$, Its fracture is abfolutely vitreous, like that of glars.

$3^{d}$, Its fpecific gravity, afcertained by Haüy, is $4^{\circ} 0497$.

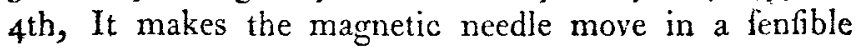
manner.

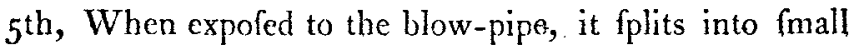
fragments, which fly to a confiderable diftance in bright red fparks, which, when they detach themfelves, produce a ftrong rrackling noife. What remains of the Itone has a grayithwhite colour, and does not fufe completely.

$6 \mathrm{th}$, When heated with borax it fufes, and communicates to that falt a yellow colour inclining to violet.

7 th, A hundred parts of this fubitance, expofed to heat in a platina crucible, lofe eight parts of their weight, and the matter affumes an ochry red colour. If, from the quantity. of iron it contains, we eftimate the oxygen it muft abforb by the operation, we fhall find that it has loft about i 1 per cent.

\section{Pbanomena wbich the Gadolinite exbibits with the Mineral Acids.}

The gadolinite (it is by this name I thall diftinguifh this ft ne in the courfe of this memoir,) is attacked by the powerful mineral acids, fuch as the fulphuric, the nitric, and the 
muriatic; and, if their action be affifted by a gentle heat, they form a thick jelly of a grayih or yellowifh colour. If this kind of jelly be then evaporated to drynels, and the refiduum of the evaporation be wafhed in water, you will obtain filex under the form of a white powder, which, when well wafhed and brought to a red heat, gives by its weight the proportion in which it exilts with the other principles.

The folutions of gadolinite in acids do not all exhibit the fame phænomena by evaporation. The fulphuric and muriatic acids retain the iron and the new earth in combination, and nothing but the filex is feparated; while, on the contrary, the nitric acid abandons at the fame time the filex and the oxyd of iron, which may be eafily conceived from the properties of the nitrat of iron.

I took advantage of this property in preference to any other, in order to apply it to the analyfis in queftion.

I diffolved roo parts of gadolinite in nitric acid fufficiently diluted with water, and fubjected it to evaporation, expofing it to a little heat towards the end, to effect a complete decompofition of the nitrat of iron. By re-diflolving it in avater, I obtained, combined with the nitric acid and diffolved, the peculiar earth feparated from the iron and the filex. While my folution ftill retained fome traces of iron, which I eafily perceived either by the reddith colour or by the gallic acid, I again evaporated the liquor to drynefs, or $I$ added a drop of ammonia, and the iron was then precipitated under the form of yellowinh flakes, which I feparated by the filter.

To feparate the iron from the filex, I boiled the mixture in muriatic acid a little concentrated; I then diluted the folution with water, and made it pafs through the filter, in order that I might collect the filex, and wafh it till it was no longer precipitated by ammonia.

In regard to the new earth diffolved in nitric acid, it will be fufficient if "it be pure to precipitate it by ammonia, and to wafh it to obtain it feparate; but having learned, by preliminary trials, that in this tate it is mixed with fmall quantities of lime and magnefia, I was obliged to employ fome further means for accomplifhing that end. 
I neverthelefs began to precipitate it by means of ammonia, which does not precipitate lime. I then poured into the liquor, united to the wahings of the precipitate, fome drops of a folution of common carbonat of potalh, and $I$ obtained the lime combined with the carbonic acid. I rediffolved, for the third time, in nitric acid, the earth mixed with the oxyd of manganefe, and added, in fmall quantities at a time, a folution of hydro-fulphuret of potath, in order that I might precipitate only the metallic parts, which, with a litule attention, I was able to effect.

I had then the earth alone, fo that nothing was neceffary to obtain it pure but to precipitate it by ammonia.

\section{Analyses of the Gadolinite by Potak.}

I fill employed another method, which alfo fucceeded, to feparate the different elements which conftitute the gadolinite: it confifts in fufing it with two parts of cauftic potath, wahing the mars with boiling water, and filtering the liquor, which has a beautiful green colour.

In evaporating this liquor, the manganefe, which gave it its colour, was gradually precipitated under the form of a black powder, which could be eafly collected by decanting the fupernatant water.

When it is obferved that there is no more oxyd of manganefe, the liquor mult be faturated with nitric acid: on the other hand, the fediment muft be put to digeft with the fame acid much diluted with water: by thefe means the earth alone diffolves, producing a great deal of heat; and the filex, and the iron too much oxydated, do not diffolve.

This folution with the above liquor, faturated with nitric acid, muft be evaporated to drynefs, in order that if any parts of iron and filex have remained they may be feparated: in other refpects the procefs is the fame as before. The latter has the advantage of feparating the manganefe from the other principles, and of rendering unneceffary an operation the fuccefs of which is difficult:

The gadolinite might alfo, rigoroufy fpeaking, be analyfed by direetly attacking it by the fulphuric and muriatic acids; but as thefe acids diffolve at the fane time, and 
without diftinction, all the elements which compofe this ftone, a hydro-fulphuret mutt be employed to feparate the metals; and the juft management of this operation is diffcult, becaufe the new earth is precipitated by an excefs of the re-agent.

By the help of thofe means, which I have briefly explained, I was able to difcover and feparate the fubftances which enter into the compofition of the ftone called gadolinite. Thefe fubftances are filex, black oxyd of iron, lime, oxyd of manganefe, and the peculiar earth to which M. Ekeberg bas given the name of Ytria.

The proportions in which they are found are as follow:

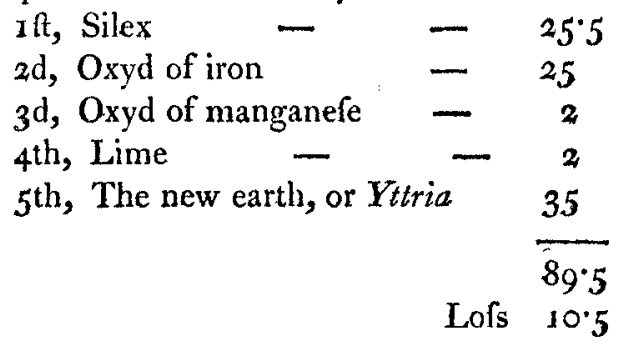

Thefe $10^{\circ} 5$ form the fmalleft lofs I experienced in the different analyfes I made; for I thought it neceffary to employ, in confructing this table, the greateft quantities of each of the matters obrained by either of the proceffes.

I at firt thought that this lofs arofe from fome alkaline fubftances, as is the cafe in feveral kinds of ftone; but, having treated 100 parts by fulphuric acid, I affured myfelf that it arofe from another caufe; for, having precipitated by ammonia all the earthy and metallic matters diffolved in the fulphuric acid, and having brought to a red heat the falt produced by evaporating the liquor to drynefs, there remained nothing in the crucible but a little fulphat of lime.

As I fufpected that this was occafioned by fome volatile fubftance, I heated, in a platina crucible, 100 parts of the ftone reduced to powder, and found that it had decreafed eight parts, and that the remainder had affumed a yellowifh colour.

The light effervefcence which I had always remarked 
when the ftone was diffolved in acids, induced me to imagine that one part at leaft of the deficit was owing to the carbonic acid.

To affure myfelf of it, I introduced into a fmall phial 100 parts of the matter in powder, and, after preparing a glafs tube, deftined to convey the gas into the lime-water, I poured into it fulphuric acid diluted with a certain quantity of water; a fwelling up and heat were produced, and fome air-bubbles paffed into the lime-water, by which it was rendered turbid; but the quantity of the precipitate was fo fmall, that it was impofible for me to meafure it. As the fpace, indeed, in the veffels which renained empty was fo great, it is probable the greater part of the carbonic acid remained in it.

But this experiment fufficiently proved to me that the $10^{\circ} 5$ of lof $s^{\cdot}$ belonged not merely to the carbonic acid; for, though the fpace furnifhed by my veffels was pretty confiderable, it would not have been capable of retaining it, and I fhould alfo have obtained a greater quantity of calcareous precipitate: In the hope of finding fome other fubftance, which, with carbonic acid, might contribute to form this lofs, I put 100 parts in a retort of luted glafs, to which $I$ adapted a fmall receiver, and $I$ expofed it to a ftrong heat. There appeared in the neck of the retort, and even in the bottle, fome fmall drops of water, the quantity of whith was fo fmall that I could not weigh it. But the matter taken from the retor weighed no more than gr parts. Thus it appeared to me that the lofs which 1 experienced in my analyfes is chiefly owing to water and carbonic acid.

Having given the moft remarkable characters of the foffil called gadolinzte, and the proceffes which appeared to me beft adapted for feparating its principles, I thall now briefly explain fome of the properties exhibited by the new earth extracted from it.

Ift, It is perfectly white; but it is pretty difficult to obtain it in that ftate on account of the oxyd of manganefe; which follows it in almoft all its combinations.

2d, It has neither favour nor fmell. 
$3^{d}$, It is not fufible alone, but with borax it forms a white glars, which is tranfparent when it has not been added in excefs.

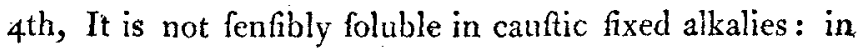
this it is different from alumine and glucina, which combine with thefe very eafily and in large quantity.

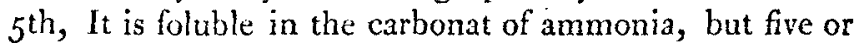
fix times lefs fo than glucina; that is to fay, five or fix times more carbonat of ammonia is required to diffolve an equal quantity of yttria:

6 th, It combines rapidly with the fulphuric acid, and produces heat in proportion as the union is effected: the falt thence refulting cryftallifes in fmall brilliant grains little foluble in water: it appeared to me that more than fifty parts of cold water were neceflary to diffolve it, efpecially when not accumpanied with an excefs of acid. It has a tafte at firt aftringent, and afterwards fweet, like fugar or falt of lead. This property, though analogous to that of glucina, is, however, fo fenfibly different from it, that by comparing them they may be eafily diftinguithed.

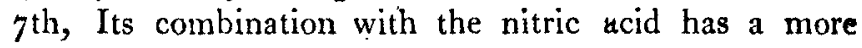
friking favour, but it produces in the mouth an effect of the fame nature: it cryftallifes only with difficulty, and its affinity for water is fo great, that it requires fome trouble to dry it. During this operation, if it be expofed to too much beat, inftead of becoming folid, like the greater part of the falts, it grows foft, and affumes the appearance of thick tranfparent honey; by cooling, it becomes hard and brittle like a ftone; when expofed to the air, it attracts the moifture of it, and becomes foft.

The fulphuric acid, poured into a folution of the nitrat of yttria, forms in it a cryftalline precipitate, which is a fulphat of the fame earth.

8th; The combination of this earth with the muriatic acid exhibits nearly the fame phænomena, in the feveral experiments I made, as the nitrat above examined: like the nitrat it can be dried with difficulty, it is fufible by a gentle heat, and ftrongly attracts the moifture of the atmofphere.

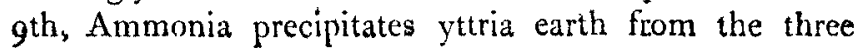
Vol. VIII. 
combinations above mentioned; lime and barytes produce much more fenfibly the fame effect.

roth, The oxalic acid, and confequently the oxalat of ammonia, form in its folutions precipitates which have an appearance abfolutely fimilar to that of the nuriat of filver: glucina with the oxalic acid forms a very foluble falt-a new difference between thefe two earths.

$x$ th, Pruffiat of potaln cryftallifed and re-diffolved in water occafions, in the folutions of this earth by acids, a white granulated depofit; but this is not the cafe in folutions of glucina.

I2th, The phofphoric acid does not precipitate it from the other acids, but the phof phat of foda feparates it under the form of gelatinous white flakes.

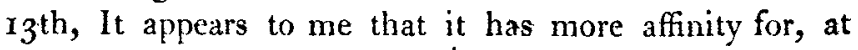
leaft, fome of the acids, than glucina has.

$14^{t h}$, It precipitates an infufion of gall-nuts in brown flakes.

From what I have faid, a great number of analogies may without doubt be obferved between this earth and glucina; but, at the fame-time, there appear differences which do not permit us to confound thefe two earths. Thefe differences chiefly are, the infolubility of the yttria and the folubility of glucina in fixed cauftic alkalies; the little folubility of the fulphat of the yttria, and the great folubility of glucina, in the fulphuric acid; the difficult folubility of yttria, and the ready folubility of glucina, in carbonat of ammonia the precipitation of yttria, and non-precipitation of glucina, from their folutions by oxalic acid and the pruffiat of potafl.

Ifere then we have nine kinds of earth very diftinet by the properties peculiar to each : foon, no doubt, we thall reckon ten, if, as we have reafon to prefage from the accuracy of M. Tromfdorf, the exiftence of that which he has lately announced under the name of augufl, in the Saxon beryl, be realifed. .

Thefe earths will increafe in a wonderful manner the number of the faline combinations, which are already very confiderable, and will furnin to chemifts a multitude of new properties to be fudied. It is to be wifhed that they may 
find fome of them applicable to the arts, in order that thefe difcoveries may not remain altogether ufelefs. It is to be withed alfo, when the properties of this new earth thall be better known, that chemilts may give themfelves the trouble to change the name of yttria, by which it is now known, and which is derived from Ytterley, the place where it is found, that another derived from its effential properties may be given to it.

I thall conclude with remarking the great difference between the refult of M. Ekeberg's analyfis and mine. I do not know exactly to what it is owing, but I can affert that, in five analyfes which I made of this fone by different proceffes, I never had lefs than 12 of lofs. I prefume that a certain quantity of moifture, and perhaps carbonic acid, remained in the new earth obtained by M. Ekeberg, for it is chiefly in this point that we differ. He found 47,5 , and I only from 34 to 35 , becaufe 1 calcined it more ftrongly.

\section{NEW PUBLICATIONS.}

A Manual of a Courfe of Cbemiftry; or, a Series of Experiments and Illuftrations neceffary to form a complete Courfe of that Science. By J. B. BouIlLon Lagrange, Profelfor in the Central Scbools of Paris, Coc. Tranflated from the French, with 17 Plates. 2 Vols. I8 Shillings. Cuthel, and Vernor and Hood, i8oo.

[Continued from Page z8z.]

IN our laft we announced the publication of this ufeful work, and promifed a few extracts. We now fubjoin the following.

Citric Acid [Concrete juice of lemons].

Scheele was the firt perfon who found means to obtain the citric acid cryftallized, and well feparated from the mucilage, which accompanies it in the juices of thofe fruits that furnifh it.

The procefs for obtaining this acid, according to that chemift, is as follows : Exprefs the juice of lemons, and leave it 